Finisterra, XXXIII, 65, 1998, pp. 185-193

\title{
GEOPOLITICAL PERSPECTIVES IN SPAIN: FROM THE IBERISMO OF THE 19th CENTURY TO THE HISPANOAMERICANISMO OF THE $20^{\text {th }}$
}

\author{
JOSÉ ANTONIO RODRÍGUEZ-ESTEBAN ${ }^{1}$
}

\begin{abstract}
Abstact: The changes which took place in the balance of power in Europe in the last thirty years of the $19^{\text {th }}$ century, together with the process of colonial expansion and partition, led Spanish geographers to see the need to combine the territorial projects and interests of Spain and Portugal with the aim of defending what remained of their colonial empires, coveted by English-speaking countries. This gave new life to a school of thought known as "Iberismo", which now extended to include France in the formula of a "triple alliance of the South" based on the common interests of Latin countries. The failure of both attempts at rapprochement gave rise to these ideas being transferred, by the beginning of the $20^{\text {th }}$ century, to the Spanish-speaking countries of America. Iberismo was to become "Hispano-Americanismo", and the defence of strategic and material interests was to begin with a reaffirmation of the moral and spiritual qualities of peoples sharing common roots and a common language. Ideas and arguments along these lines were then developed on both sides of the Atlantic, crossing boundaries into other spheres of intellectual activity.
\end{abstract}

Key-words: Iberismo, Hispanoamericanismo, Triple alliance of the South, History of Spanish Geography, colonialism, external policy, Sociedad Geográfica de Madrid.

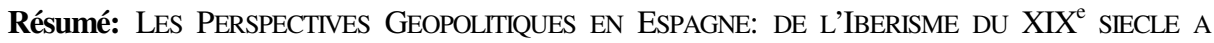
L'HISPANOAMERICANISME DU XX ${ }^{\mathrm{e}}$ SIECLE - Les changements qui se produisent dans l'équilibre de forces européen durant le dernier tiers du $\mathrm{XIX}^{\mathrm{e}}$ siècle, qui vient s'ajouter à un processus d'expansion et de distribution territoriale, conduisent les géographes espagnols à essayer de faire marcher ensemble les projets et les interêts territoriaux de l'Espagne et du Portugal; les deux pays possédaient des colonies historiques convoitées par les pays du domaine anglosaxon. Le courant de pensée connu comme "Ibérisme" se revitalise à ce moment, s'étendant à la France sous la formule de la Triple Alliance du sud, et s'appuyant sur les interêts communs des pays du domaine latin. L'échec des deux essais de rapprochement a donné lieu au déplacement de ces idées dès le début du $\mathrm{XX}^{\mathrm{e}}$ siècle vers les pays américains de langue espagnole. L'Ibérisme se transforme ainsi en Hispanoaméricanisme et la défense des intérêts stratégiques et matériels se limite à la revendication des qualités morales et

1 Profesor. Departamento de Geografía. Universidad Autónoma de Madrid. 28049 Madrid, España. Tel.: 3491 3974576; Fax: 3491 3974042; E-mail: josea.rodriguez@uam.es 
spirituelles des peuples qui partagent l'origine et la langue. Ces idées et ces raisonnements se sont développés des deux côtés de l'Atlantique en s'élargissant vers d'autres secteurs intellectuels.

Mots-clés: Ibérisme, Hispanoaméricanisme, Triple Alliance du sud, Histoire de la Géographie de l'Espagne, colonialisme, politique extérieure, Sociedad Geográfica de Madrid.

Resumo: PeRsPectivas GeOPOLITICAS EM ESPANHA: DO IBERISMO DO SÉCUlO XIX AO HISPANOAMERICANISMO DO SÉCULO XX - As alterações que se produzem no equilíbrio de forças europeu no último terço do século XIX, aliado a um processo de expansão e partição colonial, levaram os geógrafos espanhóis a tentar conjugar projectos e interesses territoriais de Espanha e Portugal, com o objectivo de defender o que restava dos respectivos impérios coloniais, cobiçados pelos países anglo-saxónicos. Revitaliza-se, assim, uma corrente de pensamento conhecida por "Iberismo", que agora inclui também a França sob a fórmula "Tripla aliança do Sul”, apoiada em interesses comuns dos países latinos. $\mathrm{O}$ fracasso das duas tentativas de aproximação fez deslocar estas ideias para a América Latina, a partir do início de século XX. O "Iberismo" transforma-se, assim, em "Hispano-americanismo", limitando-se à defesa de interesses estratégicos e materiais e à reafirmação das qualidades morais e espirituais de povos que partilham língua e origens comuns. Estas ideias e argumentos foram-se desenvolvendo dos dois lados do Atlântico, alargando-se a outras esferas intelectuais.

Palavras-chave: Iberismo, Hispano-americanismo, Tripla aliança do Sul, História da Geografia espanhola, colonialismo, política externa, Sociedade Geográfica de Madrid.

\section{EUROPEAN GEOPOLITICS: IBERISMO AND THE SOUTHERN ALLIANCE}

A series of events which occurred in continental Europe during the second half of the $19^{\text {th }}$ century gave rise to a process of rapprochement between certain intellectual circles in Spain and Portugal, amongst which were the group of geographers comprising the geographical societies in Spain, who interpreted the altered European status quo in geographical terms. The proposed a series of economic and political measures which would enable an alliance to be created between Spain and Portugal, capable of being extended to include France, under the title of the "triple alliance of the South" alluding, in words of the day, to the common interests of Latin peoples as against those involved in the process of colonial expansion, which would allow the former nations to recover a leading role in the international arena.

Amongst the most significant events which took place in continental Europe was the change in the balance of power brought about by the Franco-Prussian war of 18701871, demonstrating the supremacy of northern (from the viewpoint of the Iberian Peninsula), over southern countries, which came to have the effect, for the process it is wished to discuss here, of Spain and Portugal being seen as small peripheral powers which needed to form alliances if they were to be able to sustain their external policy (JOVER ZAMORA, 1979).

This fact acquired particular importance after the start, in the years immediately 
following the conflict, of the process of colonial expansion being carried on in particular by European countries, which was to entail also a process of colonial redistribution involving the possessions of those countries which had inherited colonial empires, as had Spain and Portugal. The substantial change implied by the doctrine which came out of the Berlin Conference in relation to title to land, replacing paramountcy with effective occupation of land, was to pose a clear threat to the overseas possessions of the countries of the Iberian Peninsula. Portugal's territorial conflicts with England and those of Spain also with England, Germany and the United States acted as a catalyst for the progress of the ideas of rapprochement between Latin countries developed by Spanish geographers.

The processes of national unification which had taken place in Germany and Italy had given rise to a current of thought and action aimed, under the name "Iberismo", at achieving the unification of Spain and Portugal also. This notion was linked to a process of political change which also involved their transformation from monarchies into republics, and it was precisely liberal and republican politicians, with strong support from their French colleagues, who prior to 1870 kept alive the ideal of Iberismo, an ideal which was naturally opposed by monarchists and conservatives.

The economic crisis of the eighteen seventies and the coming to the fore of conservative policies, together with the restoration of monarchies in Spain and Portugal, gradually relegated this Iberist notion, replacing it with the age-old fear of rapprochement between Spain and Portugal as invasion and domination of Portugal by Spain, recalling what had taken place between 1580 and 1640. During this period Spanish kings ruled the whole peninsula sowing a distrust of things Castillian which came to form part of the Portuguese collective memory from that time. This distrust, had sustained the alliance between Portugal and England since that time as was pointed out repeatedly in the historiography of the peninsula, given new life at certain times by the declarations of a number of Spanish monarchs and politicians on the unification of the peninsula.

Thus, when the change in the status quo occurred in the eighteen seventies and eighties, Iberist thinking was not only clearly on the wane, but was being firmly combated by Iberian monarchs with the support of their European counterparts. This meant also that the alliance systems of the monarchist governments were going in the direction of the alliance between Portugal and England referred to above, and Spain during this period was pursuing the conservative policies which have come to be known as the "recogimiento" (withdrawal), aiming not to become engaged in external actions until it had resolved the serious problems it was experiencing at home.

It was against this national and international background that Spanish geographers put forward their proposal for a rapprochement with Portugal under the name of the "triple alliance of the South" based on geopolitical premises in the context of the European process of colonisation. Its principal exponent in Spain was the geographer Joaquín Costa, who had been supporting it explicitly since 1880, and had made his own the Sociedad de Geografía Comercial (Commercial Geographical Society) which came into being in 1884 to give impetus to Spain's colonial and commercial policy.

Portuguese colonial policy had come into conflict with English colonial interests 
on several occasions: in Ambriz, Angola, which was settled by the military occupation of 1855, on the island of Bolama, Guinea and at Lorenço Marques, which were determined in Portugal's favour under arbitration awards by United States presidents in 1870 and 1875, when the doctrine of paramountcy still prevailed. At the Berlin Conference the new doctrine of effective occupation and of undefined spheres of influence obliged Lisbon to negotiate with France and Germany, ceding some of its historical rights. During this process Francisco Coello, president and founder of the Sociedad Geográfica de Madrid (Madrid Geographical Society), as the Spanish delegate to the Conference, expressed his support for Portugal and stated that had the latter chosen to withdraw from the talks Spain would have backed it in its stance.

In the midst of theses changes, in 1885, H. Britto Capello and Roberto Ivens made their celebrated expedition in search of a route to join the possessions on the west coast of southern Africa with those of the east, that is, to join Zaire and Mozambique. The Sociedad Geográfica de Madrid was quick to show its support for the explorers who were received in Madrid with a great display of admiration and esteem by the prime minister, Segismundo Moret, who was at the time president of the Geographical Society. This expedition resuscitated the Portuguese project of uniting its possessions from coast to coast, known as the "rose-coloured map", which clashed head on with the British desire to unite its possessions from North to South, from Cape Town to the eastern Mediterranean. This clash of interests led to the British presenting an ultimatum to the Portuguese government in 1890, demanding it abandon the area which would make this union possible, on pain of their immediately attacking the Portuguese coast. In reaction to this situation, which jeopardised the Portuguese monarchy with above all far-reaching repercussions for internal politics, the Sociedad Geográfica de Madrid hastened to send a note of unconditional support to the Lisbon society, and a document of protest which it sent to the various European geographical societies for them to put their name to the protest.

Spain for its part had also suffered colonial conflicts, initially with the loss of Borneo in the Philippine archipelago to Great Britain in 1877 and in 1884 of a number of small islands in the Caroline Islands to Germany.

In short, the new international situation had highlighted a process of redistribution of colonial possessions in favour of the large powers, the weakness of the states of the Iberian Peninsula in colonial conflicts and the subordination involved in their alliances with other powers, with Great Britain in the case of Portugal as has been seen, and in the case of Spain with Germany and Italy from 1887.

To better understand these proposals on the part of Spanish geographers for closer links between Portugal and Spain one should recall that the wish of the Sociedad Geográfica de Madrid, founded in 1876, in common with the Sociedade de Geographia de Lisboa, and as both Francisco Coello in Spain and Luciano Cordeiro in Portugal stated at the inauguration of the societies, was to make up for lost time, referring to the absence of external geographical activity, and the Portuguese society, for whom home and overseas have always been one and the same, was to throw itself immediately into this task, moving in a short space of time from a strategy of moderate and realistic 
objectives within a framework of entente with London, to a more aggressive policy, in particular after the Berlin Conference, reviving SaBandeira's old project of uniting the two shores of Africa. The Sociedad Geográfica de Madrid, for its part, kept a more theoretical course, diversifying its concerns to other spheres of internal geographical policy with issues concerning the carrying out of a land registration survey, recovering American and Spanish historical geography, analysing regional divisions in various areas of activity (administrative, judicial, ecclesiastical, military), the geographical causes of Spain's backwardness, etc., and did not launch itself onto the colonial stage until the eighteen eighties with the exploration of the western Sahara and the expansion of possessions in Equatorial Guinea following the failure of its two previous expeditions, one to recover a former possession south of the Atlas, recognised after the war with Morocco in 1860, and another to establish a port on the Abyssinian coast.

For Spanish geographers, geography constituted a route to national regeneration which would provide a firm foundation for the development of the country, in particular in terms of its links outside the country. However, in the absence of any economic impetus and as the zones of influence in the African continent had been partitioned with the northern countries clearly having the upper hand, geographers believed the only option in this field was the alliance system and that there was no better alliance than with Portugal, which possessed a colonial empire much greater than its metropolitan size and to which there was clearly only the merest economic aspect. For this reason the first movements towards rapprochement were directed at a possible customs union in the peninsula and advocated the removal of trade tariff policies in the interests of allowing competitive industry to develop. Joaquín Costa, known, for his contribution, as the great advocate of Spanish colonialism and regeneration, was to refer, in proposing the triple alliance of the South in 1885, to the close relationship between industry, protectionism and colonies, stating that: Portuguese possessions in Africa were an extremely rich market which were being exploited by everyone except Portugal; that Portugal's great African provinces, Angola and Mozambique, did not, by a long way, cover the costs involved, and proposed as a solution the development of trade favoured by the removal of customs barriers. A number of Portuguese newspapers supported these initiatives, pointing out the illogicality of the fear harboured by Portuguese people over an invasion which had lasted sixty years and which a series of historical events had turned deadly, whereas 247 years had passed with impeccable relations between them, and that the hostile stance of Great Britain to Portuguese expansion was showing that it was precisely the alliance itself which had kept mistrust alive in its relations with Spain.

Costa pointed out also that in France too concerted or joint action with Spain and Portugal in external and colonial matters was being seen in an increasingly favourable light. He saw signs of this in the reception which the Paris Commercial Geographical Society had given a few months previously to the Spanish minister Castelar in connection with the construction of a Pyrenean railway at Canfranc to create commercial links between both sides of the mountains. The president, M. Meurand spoke of Spain saying "Realisation of this project will add a new assurance and give greater impetus to 
friendly relations between the two countries united not only by their adjoining territory but also by their common roots, by affinities of language, by having the same aesthetic sensibility in the arts and humanities and by the close identity of their economic interests. We cherish the hope that this union will become even closer, continuing into the future, and will constitute a new form of family allegiance which, in place of the dynastic treaties of before, will be a family allegiance of Latin countries". Costa ended with reference to the expressions of support for Portugal by various French publications.

\section{TOWARDS HISPANOAMERICANISMO}

Celebration of the Portuguese expeditions of Capello and Ivens had provided an opportunity to demonstrate ethnic affinities and the opposition between the Latin race and the German and English-speaking race (see the statements of Segismundo Moret and Joaquín Costa), and it was precisely this opposition to other countries which was the reason behind union. In that same year, 1885, it had been planned to hold an Iberian-American geographical conference with the aim of the peoples then referred to as Ibero-Americans moving towards creation of a coherent set of ideas on economic and colonial issues. Lack of agreement on a number of matters, such as the use of the name "Iberian" with the fears raised by an assumption of union, led to the postponement of the project until two years later, to 1887, when it was hoped to use the opportunity of the inauguration of the Salamanca-Oporto railway to relaunch the project, but it would not be until 1892 that, on the occasion of the celebrations to mark the Fourth Centenary of the Discovery of America, it would meet under the name of the Congreso Geográfico Hispano-Portugués-Americano.

The conference, which was attended, with the qualified support of the Geographical Society of Lisbon and the Oporto Chamber of Commerce, out of a total of 200 delegates, by 45 Portuguese participants and 17 from the various Iberoamerican countries, raised a hymn to the Latin race, and in particular that part of it which lives on the peninsula which, although held to be a mixture of peoples, has its own distinctive characteristics, the product of physical and geographical conditions, which make it the best suited to colonisation, with, amongst other qualities, its great capacity for expansion.

Yet it is perhaps in the British ultimatum of 1890 on the Portuguese colonies and the "Spanish Disaster of 98 " that one can best see what was being said in this vein. On the occasion of the first incident the geographical societies of Lisbon and Madrid exchanged various communications in which the Lisbon society sought the solidarity of the Madrid society, which replied, laying emphasis on how "This society, which sees the Portuguese nation as brother to the Spanish ...." which description as a "brother" was never reciprocal. The Spanish society also took the step of sending a note to the other geographical bodies in Europe seeking their solidarity with Portugal, to which there put its name, amongst others, the Franco-Hispano-Portuguese Society of Toulouse, which expressed also a desire for "fraternity between Spain, Portugal and France".

Lastly, on the occasion of the war of 1898 between Spain and the USA, the Portuguese press contained similar expressions of solidarity, to be brought together in 
the Boletín de la Sociedad Geográfica de Madrid (1898), of note amongst which are those of the newspaper $O$ Século, which, government neutrality notwithstanding, was to state that: "Affinities between peoples and historical affinities are not governed by nor disappear with international conventions".

Despite these expressions of friendship, however, the process of rapprochement with Portugal could be said to have failed, and it was to normalise relations with Great Britain some time after the ultimatum. It was the loss of the overseas possessions in 1898 which was to give rise to the shifting of the proposal for an Iberian and southern alliance from the European to the American context, in a process which was equally on the periphery, now seeking ethnic affinities in a common language and common roots to reaffirm interests not now of a territorial nature but spiritual, moral and cultural. Iberismo thus became Hispanoamericanismo and the upholding of historical colonial rights turned into a defence of the original values of the first colonial activity of the $15^{\text {th }}$ and $16^{\text {th }}$ centuries, values considered more universal and more profound than those being developed at that time by the English-speaking peoples in the course of their expansion. In this vein the first efforts were to be aimed at analysing and unravelling the origins of the "leyenda negra" of colonial misdeeds built up around Philip II, to salvage the best of the civilising achievements and colonial gifts of the Hispanic world.

Clearly, Hispanoamericanismo did not come about as a reaction to the failure of Iberismo, as from the outset Spanish geographers had both processes in view, but rather as an alternative in the quest for more durable links with the outside world, as are common roots and language. There was in this way a shift in purpose from an initial, to a certain extent defensive, Iberismo, to a later Hispanoamericanismo in need of consolation and support in the face of the unbearable realisation of the loss of influence in the world: "We no longer have any mission to fulfil in the Old Continent - the geographer Beltrán y Rózpide was to say in 1904. Not one tiny plot do we retain in Asia or the Pacific. Our language can still be heard on the eastern edge of Europe and in Asia. In Africa every avenue for expansion has been closed to us. Only in America are our people still to be found, nations of our race and our tongue, vigorous green shoots of the former Spanish empire". The proposals put forward therefore went from being of a practical nature, such as the customs union of the peninsula advocated by Iberismo, to stress psychological and spiritual processes.

The new ideas gained strength with the increasing Spanish emigration to Central and South America, and centred around a growing resentment shared in Spain and Hispanic America at United States imperialist policies. A number of different opinions and events gave expression to this process of rapprochement, the ramifications of which still reach us today, in many cases in the form of the same propositions and intentions as in those initial times.

Of importance amongst Spanish geographers making the greatest contributions this century to advocating closer links between Spanish-speaking nations as the only route to advancement on the international stage is Beltrán y Rózpide, secretary of the Sociedad Geográfica de Madrid since its foundation and one of the first precursors of the study of human geography in Spain. Beltrán y Rózpide was to use not only geographical 
circles but the daily press to set out and spread his ideas on the subject. Indeed, a book containing these articles was to be entitled "Los pueblos hispanoamericanos en el siglo XX" (Hispanoamerican peoples in the $20^{\text {th }}$ century), in which he demonstrated this process of rapprochement following the loss of the Antilles and Philippines possessions in 1898. His words on the matter are eloquent: "On both sides of the Atlantic - states Beltrán in the introduction to the book -, men of Spanish race and language feel the need to strengthen links to consolidate ties already created by nature and history [...]. The memory of past grandeur, the sorrow of present misfortune and wariness of what the future was to bring led us to fix our attention all the more intently on the Spanish peoples of America and we assumed then that, through community of interests and closer dealings with the young nations they had formed it would be possible and relatively easy to broaden the narrow horizons which today restrict our external life" (BELTRÁN Y RÓZPIDE, 1904: 5-7).

In 1904 members of the Real Sociedad Geográfica de Madrid (Royal Geographical Society of Madrid) took part in various Committees brought together by the "Unión Iberoamericana", an institution dedicated to promoting relations with the countries of Hispanic America. The various proposals attempted to establish the avenues and momentum required for rapprochement; Julio Betancourt spoke of ethnic union on the grounds of the requirements of "subsistence", holding that Spain should make itself the centre of such a union; Javier de Ugarte expressed the view that governments should implement the proposal; Beltrán y Rózpide advocated, in contrast, that the forces at work in each country should prevail upon those in government and force them to act in accordance with the "supreme interests of nation and race"; and José Gutiérrez Sobral advocated an increase in production which would enable trade, and other contributors stressed the need to give more importance to geographical and statistical studies as the basis for any development (Boletín de la Real Sociedad Geográfica, 1904).

Years later the Real Sociedad Geográfica de Madrid was again to foment opinion on these matters by organising in 1914, in conjunction with the Academia de la Historia, a Hispano-American History and Geography Conference, without the participation of Portugal. A second conference would be held in 1921 and both dealt, in addition to matters relating to various elements of geohistorical research, with the cultural and civilising work carried out by Spain in America. The intention was not to affirm but to clarify, nuance and counter the "leyenda negra" in its most essential assertions, to prevent there arising between Spain and America - in the words of the Marqués de Laurencín -, "like a fence, the evil intentions forged by envy and hate". This same writer was to state that the papers presented to the conference should also indicate the path to follow "to cure us of a disease traditional in the Spanish people, that of division, of fragmentation, of family feuding, to put it that way, which has always caused us so much harm, here and over there; and once these causes are known, to put them right by encouraging the growth of spiritual unity, identity of thinking and community of ideals, infinitely superior to territorial unity, and the only unity which can restore to our race the influence, dominion and nobility which are its due by virtue of its traditions in every sphere of human activity" (CONGRESO, 1921: 35-37). 
There was created in this way a series of ideas on national affinities, given impetus and transformed by Spanish geographers according to their perception of international events, which would eventually form an important current of opinion on both sides of the Atlantic.

\section{BIBLIOGRAPHY}

BELTRÁN Y RÓZPIDE, R. (1904) - Los pueblos hispanoamericanos en el siglo XX (1876-1936). Imprenta de Administración Militar,Madrid.

CONGRESO DE HISTORIA Y GEOGRAFÍA HISPANOAMERICANAS (1921) - Actas y Memorias del II Congreso de Historia y Geografía hispano-americanas. Establecimiento Tipográfico de Jaime Ratés, Madrid.

CostA, J. (1887) - La triple alianza del mediodía. Revista de Geografía Comercial, II, Madrid: $194-200$ and 218.

JOVER ZAMORA, J.M. (1979) - 1898. Teoría y práctica de la redistribución colonial. Fundación Universitaria Española, Madrid.

MEDINA, J. (1992) - A crisis colonial dos anos noventa em Portugal e Espanha e as suas consequências para os dois países ibéricos (1890-1898). Estudo de História comparada. In H. DE LA TORRE (ed.), Portugal, España y África en los últimos cien años. IV Jornadas de Estudios luso-españoles, Universidad Nacional de Educación a Distancia, Madrid: 17-27.

RodríGUEZ Estebán, J.A. (1996) - Geografía y colonialismo. La Sociedad Geográfica de Madrid (1876-1936). Ediciones de la Universidad Autónoma de Madrid, Madrid.

RuEDA HERNÁNZ, G. (1998) - El Iberismo del siglo XIX. Historia de la posibilidad de unión hispano-portuguesa. In H. de la TORRE GÓMEZ; A. PEDRO VICENTE (dir.). España-Portugal. Estudios de Historia Contemporánea, Ed. Complutense, Madrid: 181-214.

SALOM COSTA, J. (1965) - Las relaciones hispano-portuguesas al término de la época isabelina. Hispania. Revista Española de Historia, XXV (98): 219-259.

SOCIEDAD GEOGRÁFICA DE MADRID (1890) - La cuestión anglo-portuguesa. Boletín de la Sociedad Geográfica de Madrid, XXXVI, Madrid: 110-112.

SOCIEDAD GEOGRÁFICA DE MADRID (1898) - Portugal y España. La opinión y la prensa en Portugal con motivo de la guerra hispano-yanqui. Boletín de la Sociedad Geográfica de Madrid, XXVIII, Madrid: 40-57.

TORRE GÓMEZ, H. (1991) - "Portugal y España en el horizonte europeo en la crisis del cambio de siglo (1890-1919)". In H. de TORRE (coord.). Portugal, España y Europa. Cien años de desafío (1890-1900), III Jornadas de Estudios Luso-Españoles, Universidad Nacional de Educación a Distancia, Mérida: 11-32. 